\title{
Precipitation in Interstitial Free High Strength Steels
}

\author{
Pampa GHOSH, Chiradeep GHOSH and R. K. RAY \\ R\&D Division, Tata Steel Limited, Jamshedpur, India. E-mail: pampa.ghosh@tatasteel.com, chiradeep.ghosh@tatasteel.com, \\ rkray@iitk.ac.in
}

(Received on November 17, 2008; accepted on February 16, 2009)

\begin{abstract}
An overview of the different types of precipitates in Interstitial Free High Strength (IFHS) steels has been presented. Details regarding their sequence of formation during processing, their morphologies and chemical compositions have been discussed. Correlation between precipitation and final properties has also been pointed out.
\end{abstract}

KEY WORDS: interstitial free high strength steels; precipitation; TEM; SEM; EDS; CBED; nano-beam; carbon extraction replica; annealing; texture.

\section{Introduction}

It has been some 40 years since the first industrial production of Interstitial Free (IF) steels began and the past two decades have seen the growth in production and demand for the same. The IF steels find wide application in the auto industry due to their superior formability over conventional low carbon steels. Generally, in these steels the content of interstitial elements $(\mathrm{C}$ and $\mathrm{N})$ is kept below $30 \mathrm{ppm}$ by using modern day vacuum degassers followed by addition of $\mathrm{Ti}$ and/or $\mathrm{Nb}$. These microalloying additions form carbide and nitride precipitates and thus make the matrix almost "pure", i.e. free from interstitial elements. However, with further thrust in weight reduction, in order to meet environmental norms and to increase fuel efficiency, the recent trend is to move towards the application of more and more high strength materials. Thus the high strength version of Interstitial Free steels, commonly known as IFHS steels, have been produced and these are being widely accepted by the automobile manufacturers. IFHS steels contain mainly $\mathrm{P}$ and $\mathrm{Mn}$ as solid solution strengthening elements. Here the aim is to achieve higher strength compared to normal IF steels without sacrificing much of its deep drawability. However, deterioration of drawability has often been noticed in IFHS grade steels, which has very often been attributed to the presence of $\mathrm{P}$, the principal solid solution strengthening element in this grade.

IF steel is termed as 'clean steel' as the total volume fraction of precipitates is very less. In spite of this the precipitates appear to have a very significant effect on the properties of IF steels, especially formability. ${ }^{1-3)}$ One would expect that the IFHS steels, which contain higher amounts of alloying elements, to have higher volume fraction of precipitates and therefore the final properties are expected to be more sensitive to the overall precipitation behavior.

Researchers, especially DeArdo and his group, ${ }^{4-8)}$ have extensively studied and reported the precipitation behavior of IF steels. However, there is no systematic report till date on the nature and extent of precipitation in IFHS steels. In the recent past, the present authors have shown strong correlation between precipitation and texture formation in IFHS steels. ${ }^{9-12)}$ In the present contribution the authors would attempt to focus on the overall precipitation behavior of IFHS steels, taking composition and mill processing parameters as variables.

\section{Experimental}

The steels chosen for this study can broadly be classified in two groups; batch annealed IFHS (BA-IFHS) and continuous annealed IFHS (CA-IFHS) steels. The chemical compositions of the steels are given in Table 1. Table 2 lists the processing parameters of the steels. The steel compositions are chosen such a manner that the effect of composition (especially $\mathrm{P}, \mathrm{Ti}$ and $\mathrm{Mn}$ ) on the precipitation behavior of IFHS steels, can be studied independently.

For microstructural investigation and to reveal larger sized precipitates Scanning Electron Microscopy (SEM) was carried out in a FEI Quanta-200 SEM operated at $20 \mathrm{kV}$. Energy Dispersive Spectrometry (EDS) was used to determine the chemical compositions and there by identify the precipitates. For this purpose carefully polished samples were etched in Nital (Nitric acid in Ethanol) solution (2-5\%) for 10-20 s and observed in the SEM. EDS spectra were taken from the area of interest for a dwell time of $50 \mathrm{~s}$.

In the present investigation, Transmission Electron Microscope (TEM) has been the key characterization technique used. To study the precipitation behavior of the experimental steels in detail, both Carbon Extraction Replica and Thin Foil Method have been employed. In the carbon extraction replica method the extracted precipitates can clearly be revealed in a TEM without being affected by the surrounding strain field as in the thin film technique. In this method it is very easy to identify the precipitates by the EDS technique since there is no chance of interference from the matrix. However, using this method it is just not 
Table 1. Chemical compositions of the steels (in wt $\%$ ).

\begin{tabular}{|c|c|c|c|c|c|c|c|c|}
\hline Steel & $\mathrm{C}$ & $\mathrm{Mn}$ & S & $\mathrm{P}$ & $\mathrm{Al}$ & $\mathrm{Ti}$ & $\mathrm{Nb}$ & $\mathrm{N}$ \\
\hline BA-1 & \multirow{6}{*}{$<0.004$} & 0.84 & \multirow{6}{*}{$<0.01$} & 0.091 & \multirow{6}{*}{$0.03-0.05$} & 0.070 & 0.030 & \multirow{6}{*}{$<0.004$} \\
\hline BA-2 & & 0.75 & & 0.086 & & 0.065 & 0.029 & \\
\hline BA-3 & & 0.50 & & 0.058 & & 0.041 & 0.018 & \\
\hline BA-4 & & 0.38 & & 0.050 & & 0.035 & 0.005 & \\
\hline CA-1 & & 0.38 & & 0.048 & & 0.035 & 0.001 & \\
\hline CA-2 & & 0.37 & & 0.048 & & 0.04 & 0.046 & \\
\hline
\end{tabular}

Table 2. Processing parameters of the IFHS steels.

\begin{tabular}{|c|c|c|c|c|c|}
\hline \multirow[b]{2}{*}{ Steel } & \multicolumn{3}{|c|}{ Hot Rolling } & Cold & Annealing \\
\hline & $\begin{array}{c}\text { Slab } \\
\text { Reheating } \\
\text { Temperature } \\
\left(\mathrm{SRT},{ }^{\circ} \mathrm{C}\right)\end{array}$ & $\begin{array}{c}\text { Finish } \\
\text { Rolling } \\
\text { Temperature } \\
\left(\text { FRT },{ }^{\circ} \mathrm{C}\right)\end{array}$ & $\begin{array}{c}\text { Coiling } \\
\text { Temperature } \\
\left(\mathrm{CT},{ }^{\circ} \mathrm{C}\right)\end{array}$ & $\begin{array}{l}\text { Cold Roll } \\
\text { Reduction } \\
(\%)\end{array}$ & $\begin{array}{c}\text { Furnace } \\
\text { Temperature } \\
\left({ }^{\circ} \mathrm{C}\right)\end{array}$ \\
\hline BA-1 & \multirow{4}{*}{$\sim 1220$} & \multirow{4}{*}{$\sim 910$} & \multirow{4}{*}{$\sim 550$} & \multirow{4}{*}{$55-75$} & 700 \\
\hline BA-2 & & & & & 700 \\
\hline BA-3 & & & & & 700 \\
\hline BA-4 & & & & & 700 \\
\hline CA-1 & \multirow{2}{*}{$\sim 1220$} & \multirow{2}{*}{$\sim 910$} & \multirow{2}{*}{$\sim 550$} & \multirow{2}{*}{$55-75$} & \multirow{2}{*}{840} \\
\hline CA-2 & & & & & \\
\hline
\end{tabular}

possible to determine the precise sites of location of the precipitate particles, whether on grain boundaries or grain interiors.

In the carbon extraction replica method, a $200-300 \AA$ layer of pure graphite particles was deposited on the polished and etched (with Nital) samples under high vacuum. The samples with this carbon layers on the top were then etched once again and extracted precipitates embedded in the carbon layer were then fished out on Cu-grids after dipping the double etched samples in a bowl of water. The extracted replicas were examined in a Philips 200 Transmission Electron Microscope operated at $100 \mathrm{kV}$. TEM microanalysis was carried out by reducing the beam diameter. Areas as small as $20 \mathrm{~nm}$ could be selected in the TEM at an operating voltage of $100 \mathrm{kV}$ using a Field Emission Gun (FEG) source. The Convergent Beam Electron Diffraction (CBED) mode was used to take the EDS and diffraction patterns from nano-sized precipitates.

In the thin foil method of TEM study, $3 \mathrm{~mm}$ diameter discs were punched out from the thin sheet samples $(<100 \mu \mathrm{m}$ thick) and finally thinned down using jet electropolishing. An acetic acid+percholric acid solution was used for the final thinning. The composition and the jet polishing parameters were as follows:

Solution: $90 \%$ acetic acid $+10 \%$ perchloric acid

Voltage: $15-20 \mathrm{~V}$

Current: 2-5 A

Time: $20-30 \mathrm{~s}$

Temperature: sub-zero

The TEM study of the thin foils was carried out in the same TEM operated at $100 \mathrm{kV}$. Nano-beam condition was used to obtain Energy Dispersive Spectra (EDS) from the individ- ual precipitates.

\section{Precipitation in IFHS Steels}

The precipitation behavior in IFHS steels is quite complex and a variety of precipitates with different morphology, size, shape and composition were observed. An overall idea of the different precipitates found in the experimental IFHS steels will be presented here, which will include their compositions, sizes, morphologies, distributions, crystal structures and also stability. Apart from this, the effect of precipitation on the property of IFHS steels will also be touched upon very briefly.

\subsection{Precipitates in IFHS Steels}

The following precipitates were observed in the experimental steels.
$\circ$ TiN
$\mathrm{CuS}$
- TiS
$\circ \mathrm{Ti}_{4} \mathrm{C}_{2} \mathrm{~S}_{2}$
- $\mathrm{MnS}$
- $\mathrm{TiC}$
○ $\mathrm{Fe}(\mathrm{Ti}+\mathrm{Nb}) \mathrm{P} / \mathrm{FeTiP}$
- FeTi

\section{TiN}

Large TiN particles $(1-3 \mu \mathrm{m})$ are the most common precipitates detected in all the steels. The fcc crystals of TiN (lattice parameter $a=4.24 \AA$ ) can form in the liquid as well as in the solid phase. ${ }^{13)}$ As the solubility of TiN is very low in Fe the full stabilization of $\mathrm{N}$ is expected in the IFHS steels. ${ }^{14-16)}$ The amount of $\mathrm{Ti}$ (in wt\%) required to tie up with $\mathrm{N}$ is 3.42 times of the $\mathrm{N}$ present in the steels. ${ }^{6,17)}$ In IFHS steels $\mathrm{N}$ is generally kept below $40 \mathrm{ppm}$ and thus maximum Ti required to tie up with $\mathrm{N}$ is $0.014 \mathrm{wt} \%$. So we can expect in the current steels that the entire $\mathrm{N}$ is removed from the solid solution as the $\mathrm{Ti}$ content is much higher than the required $0.014 \mathrm{wt} \%$. However, as one can expect, CA-IFHS steels show smaller TiN precipitates $(\sim 1 \mu \mathrm{m})$ than their batch annealed counterparts as the annealing time is very short during continuous annealing. Again among CA-IFHS steels the size and frequency of TiN precipitates are perceptibly higher in $\mathrm{Ti}+\mathrm{Nb}$ containing steels as compared to Ti-only steels. This may be due to the presence of $\mathrm{Nb}$ which is known to increase the effective Ti solute concentration in the matrix and thus trigger the formation of TiN in the earlier stages of steelmaking. ${ }^{18)}$ It has been observed that the TiN precipitates appears as cube shaped particles, often is associated with $\mathrm{Al}_{2} \mathrm{O}_{3}$ inclusions. On many occasions sulphide precipitates are observed to be present heterogeneously on the TiN precipitates. All these features have been shown in Fig. 1.

\section{TiS}

After the formation of TiN precipitates, TiS precipitation is likely to take place. These sulphides are decomposed during hot rolling $\left(900^{\circ} \mathrm{C}<T<1200^{\circ} \mathrm{C}\right)$ and coiling $\left(600^{\circ} \mathrm{C}<T<700^{\circ} \mathrm{C}\right)$ due to their low stability at that temperature range. ${ }^{19,20)}$ Thus in the BA-IFHS steels this rhombohedral TiS ${ }^{21)}$ phase $(a=3.41 \AA$ and $c=26.50 \AA)$ is rarely observed, instead a complex precipitation of $(\mathrm{Ti}+\mathrm{Mn}) \mathrm{S}$ is encountered. However, free standing TiS particles have been observed in CA-IFHS steels and the frequency of these particles is higher in the $\mathrm{Ti}+\mathrm{Nb}$ added $\mathrm{CA}$-IFHS steel 


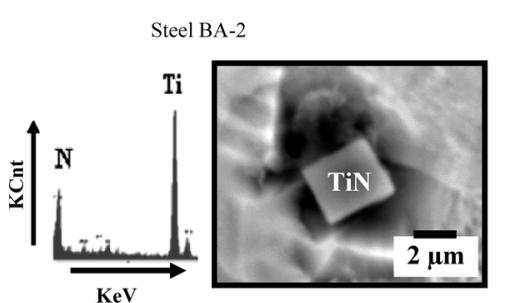

(a)

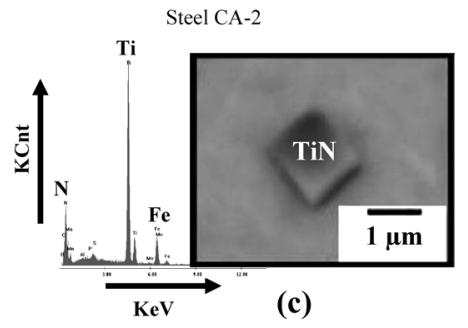

Fig. 1. SEM micrographs of the experimental steels showing presence of TiN precipitates.

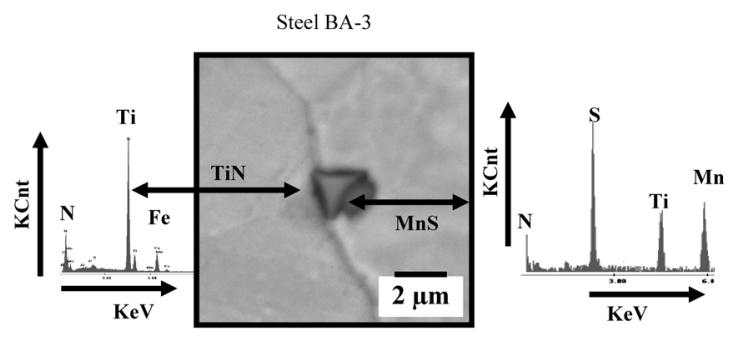

(b)

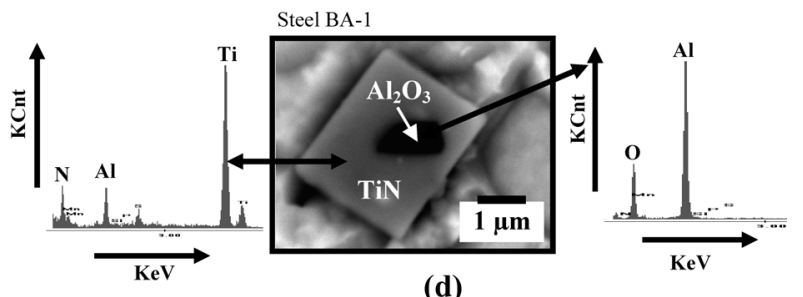

(d)
(CA-2) as compared to only Ti added CA-IFHS (CA-1) steel. This could be due to the presence of $\mathrm{Nb}$ which is known to increase the effective Ti solute concentration in the matrix and thereby stabilizing TiS at lower temperature. $^{22)}$ Figure 2 shows the different morphologies and association of TiS precipitates in the experimental steels.

\section{$\mathrm{Ti}_{4} \mathrm{C}_{2} \mathrm{~S}_{2}$}

The formation of carbosulphide particles provides an alternative mechanism to the formation of MC carbides for the stabilization of carbon in ultra low carbon steels. $\mathrm{Ti}_{4} \mathrm{C}_{2} \mathrm{~S}_{2}$ is hexagonal in structure with lattice parameters; $a=3.21 \AA$ and $c=11.20 \AA{ }^{18)}$ In general, carbosulphide precipitates are not observed in these steels except in case of BA-3 steel which shows few such precipitates of this type on few occasions. The reason could be that the steels were reheated above $1200^{\circ} \mathrm{C}$ when the carbosulphide goes into solution. Moreover, the presence of high \% of $\mathrm{Mn}$ in the BA-IFHS steels is known to suppress $\mathrm{Ti}_{4} \mathrm{C}_{2} \mathrm{~S}_{2}$ formation in the hot band and during annealing. ${ }^{19)}$ Although the Mn content of the CA-IFHS steels is much less carbosulphide particles may not get a chance to form due to the very short annealing time available. Figure 3 shows a carbosulphide precipitate present in the BA-3 steel, along with its EDS spectra and selected area diffraction pattern (SADP).

\section{$\mathrm{MnS}$}

The other kind of sulphide precipitates present in these steels is $\mathrm{MnS}$. This sulphide has a cubic crystal structure (space group: $F m 3 m$ ) with lattice parameter $a=5.226 \AA \AA^{22)}$ $\mathrm{MnS}$ forms during hot rolling at a temperature around $900^{\circ} \mathrm{C}$. It forms in all type of BA-IFHS steels, irrespective of their composition. However, in continuous annealed IFHS steels, CA-1 only shows presence of $\mathrm{MnS}$ and not the CA-2 steel. It could be due to the effect of $\mathrm{Nb}$ which promotes TiS formation over MnS. As in case of the other sulphides, MnS also does not have any particular shape and has been found to form as free standing precipitates as well as epitaxially on the TiN particles present. The sizes of these precipitates lie between $200-500 \mathrm{~nm}$. The various features of the $\mathrm{MnS}$ precipitates are observed in the experi- mental steels are shown in Fig. 2.

\section{$\mathrm{CuS}$}

Other than $\mathrm{MnS}$ and TiS, occasionally another type of sulphide precipitate containing $\mathrm{Cu}$ has also been observed in the IFHS steels. Not many researchers have reported the presence of $\mathrm{CuS}$ precipitate in these steels excepting Dupuis $^{23)}$ and Ishiguro et al. ${ }^{24)}$ This is probably because of the fact that $\mathrm{CuS}$ usually forms in combination with other precipitates and thus their presence may very well be overlooked. Figure 2(h) shows a thin foil TEM micrograph showing the presence of $\mathrm{CuS}$ and its elemental analysis in the BA-1 steel. Obviously the $\mathrm{Cu}$ has come from the trace amount present in the steel.

TiC

Carbon in solid solution is most deleterious for steel formability and therefore it has to be taken out of solution in the IFHS steels. Ti is added to tie up with carbon to form TiC, which makes the matrix 'interstitial free'. Thus the formation and control of $\mathrm{TiC}$ is very important in such steels. TiC has a fcc crystal structure (space group: $F m \overline{3} m$ ) with lattice parameters $a=4.2-4.4 \AA \AA^{4}$ ) Thermodynamically $\mathrm{TiC}$ is formed in the ferrite phase stability range $\left(\sim 700-900^{\circ} \mathrm{C}\right)$, mostly as dispersed particles. In the experimental steels fine $\mathrm{TiC}$ precipitates are observed throughout the matrix after annealing, however, their volume fraction, size and distribution vary from steel to steel. The sizes of $\mathrm{TiC}$ precipitates have been found to be larger in the BA steels as compared to their CA counterparts, although the frequency of observation of such particles is higher in the CA steels. These precipitates generally do not contain any $\mathrm{Nb}$ in them, irrespective of the $\mathrm{Nb}$ content of the steels, especially when these are present in the grain interiors. However, at or near the grain boundaries of $\mathrm{Ti}+\mathrm{Nb}$ CA-IFHS steels, the carbide precipitates are often found to contain a little $\mathrm{Nb}$. The reason is not hard to understand as $\mathrm{Nb}$ is expected to segregate at the grain boundary at the continuous annealing temperature which is $100-140^{\circ} \mathrm{C}$ higher than the batch annealing temperature $\left(\sim 700^{\circ} \mathrm{C}\right)$. It is been observed that in BA-IFHS steels, decreasing the $\mathrm{P}$ and Ti content in- 

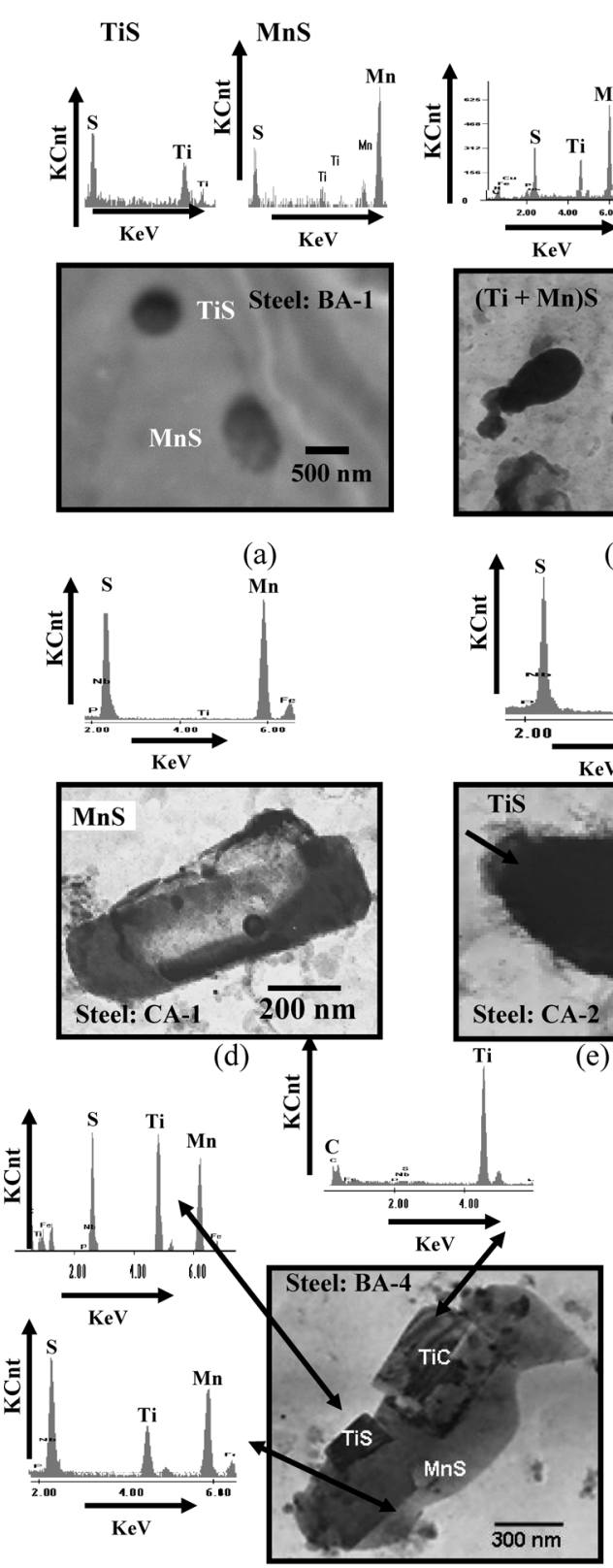

(g)

e)
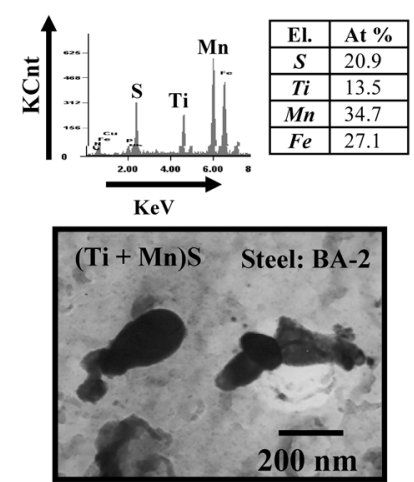

(b)
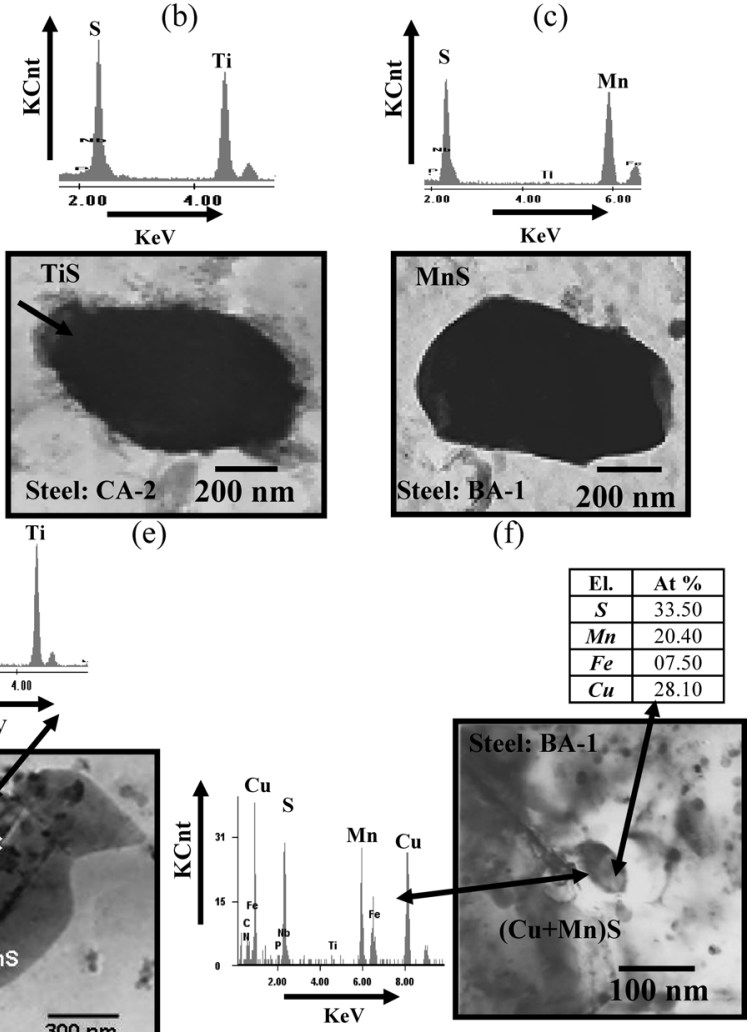

(h)
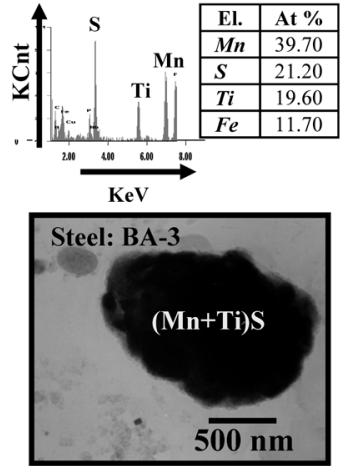

(c)
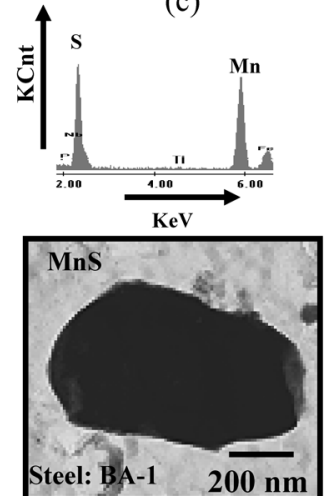

(f)

Fig. 2. Electron micrographs showing presence of different sulphide precipitates in the experimental steels. (a) SEM and (b-h) TEM extraction replica micrographs.

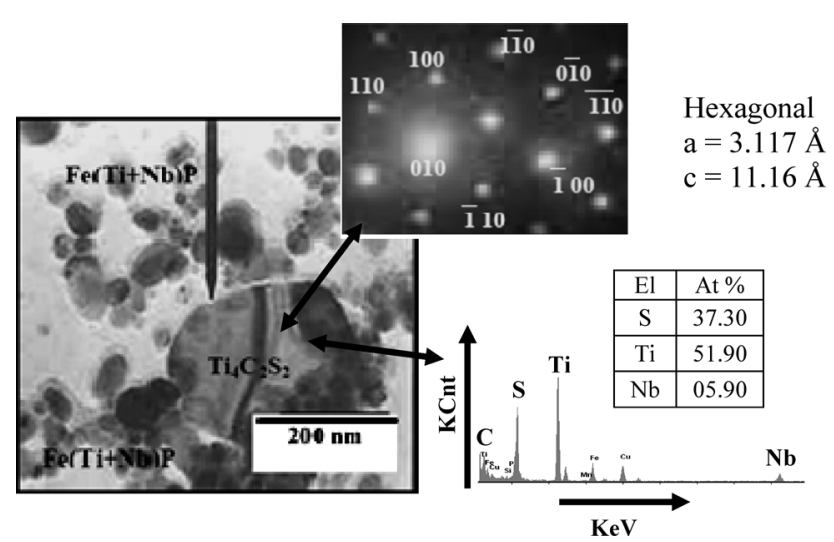

Fig. 3. TEM micrograph of Steel BA-3 showing presence of $\mathrm{Ti}_{4} \mathrm{C}_{2} \mathrm{~S}_{2}$ precipitate, its EDS with elemental analysis and Selected Area Diffraction Pattern (SADP). creases the frequency of observation of $\mathrm{TiC}$ precipitates. The reason for this will be discussed later. The various features associated with the TiC precipitates are illustrated in Fig. 4.

\section{$\mathrm{FeTiP} / \mathrm{Fe}(\mathrm{Ti}+\mathrm{Nb}) \mathrm{P}$}

FeTiP type ternary phosphide is the only phase which is observed in the higher strength version of the IF steels, i.e. in the IFHS steels, and never in the IF steels for obvious reason. FeTiP is basically a solid solution of $\mathrm{Fe}, \mathrm{Ti}$ and $\mathrm{P}$ and very often it may also contain $\mathrm{Nb}$ in it, provided $\mathrm{Nb}$ is there in the steel. It has an orthorhombic crystal structure with $a=5.939-6.105 \AA, b=3.800-3.817 \AA$ and $c=7.151-$ $7.171 \AA$. It has been observed that presence of $\mathrm{Nb}$ in the FeTiP type of precipitate increases the $c$-axis substantially. ${ }^{25)}$ The presence of this precipitate has been found to be highly deleterious for the formability of IFHS steels as it 


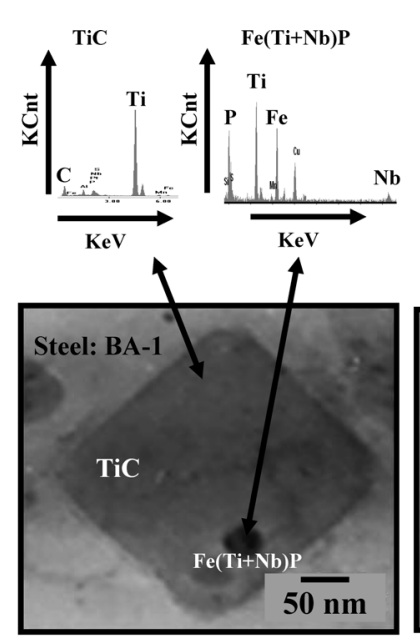

(a)

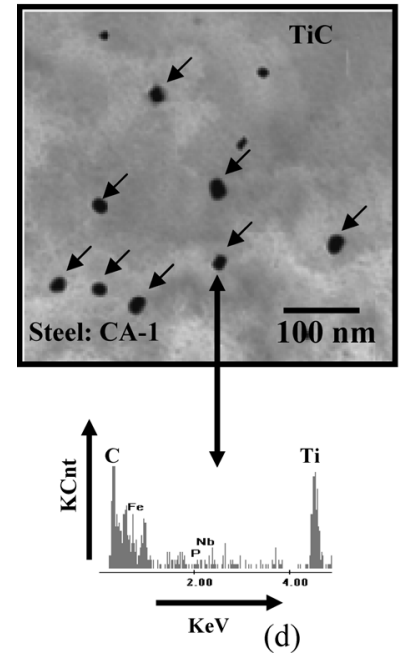

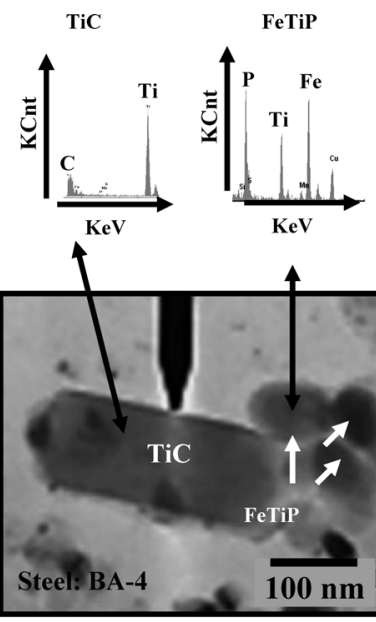

(b)

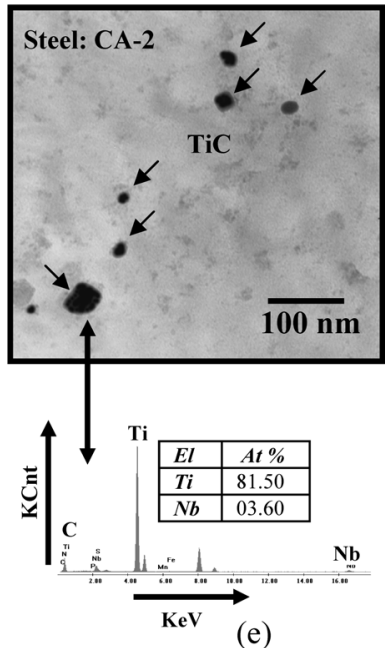

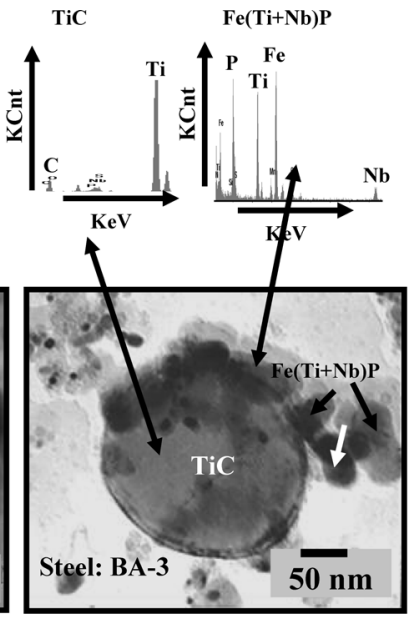

(c)

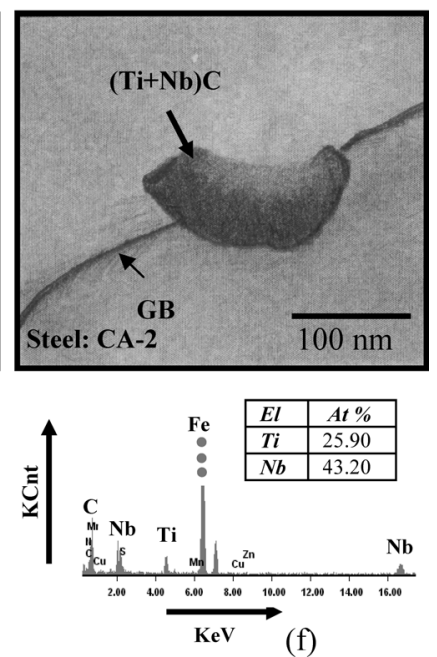

Fig. 4. TEM micrographs with EDS spectra of experimental steels showing presence of carbide and FeTiP type precipitates in the experimental steels. (a-e) Extraction replica micrographs, (f) thin foil micrograph.

adversely affects the formation of the beneficial $\{111\}$ texture. Thus controlling the formation of such precipitates is of utmost importance in IFHS steels. This will be discussed in detail in the next section.

FeTiP has been observed in BA-IFHS steels quite frequently, irrespective of their composition, with a $\mathrm{Fe}: \mathrm{Ti}: \mathrm{P}$ ratio close to $1: 1: 1$. However, in CA-IFHS steels these are rarely observed and wherever present they do not maintain a strict $1: 1: 1$ ratio for Fe:Ti:P. Higher P, higher Ti BAIFHS steels show a higher volume fraction of FeTiP type of precipitates as compared to lower P, lower Ti steels. Invariably these precipitates contain some $\mathrm{Nb}$ in them. The FeTiP precipitates may be of different shapes, ranging from globular, rectangular, elliptical, lenticular, etc. These precipitates are observed to be present both inside the grains as well as on the grain boundaries. The various features associated with the FeTiP type precipitates have been illustrated in Fig. 5. Very often these precipitates form epitaxilaly over existing precipitates, such as $\mathrm{TiC}, \mathrm{MnS}$, etc. This feature is shown in Fig. 4.

\section{FeTi}

In the present study a rather new type of precipitate has been occasionally noticed. EDS spectra taken from these precipitates only show presence of Fe and $\mathrm{Ti}$ and no other elements. This precipitate could only be observed in case of the CA-IFHS steels and not in the BA-IFHS steels. It is likely that during annealing of the cold rolled steel, Fe and Ti instantaneously form some clusters and P starts diffusing in slowly. In case of continuous annealing there is not enough time for the $\mathrm{P}$ atoms to diffuse completely, resulting in Fe-Ti compounds with very little or no $\mathrm{P}^{10)}$ However, such conditions are present during batch annealing and therefore formation of stoichiometric FeTiP particles is possible in the BA-IFHS steels. Figure 5(d) shows presence of $\mathrm{Fe}-\mathrm{Ti}$ type of precipitates in the CA-IFHS steels. More detailed work is needed to understand the exact phenomenon leading to the formation of $\mathrm{FeTiP} / \mathrm{FeTi}$ precipitates in BA/CA IFHS steels.

\subsection{Composition-Precipitation-Stability Maps for IFHS Steels}

Based on the results of the present study as well as research of various authors ${ }^{9-12,19,26)}$ obtained from literatures schematic composition-precipitation-stability maps for BA-IFHS steels have been drawn and shown in Fig. 6. As can be seen there is a little difference between high $\mathrm{P}$, high Ti steels and low P, low Ti steels regarding the formation of FeTiP and TiC. Figure 7 shows that the solubility product values of $\mathrm{TiC}$ and FeTiP are quite close. ${ }^{27,28)}$ This indicates 


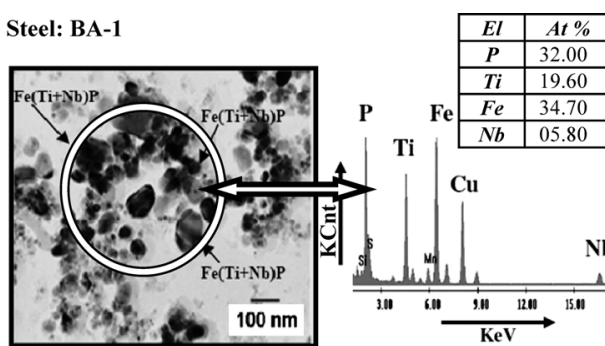

(a)

Steel: BA-4
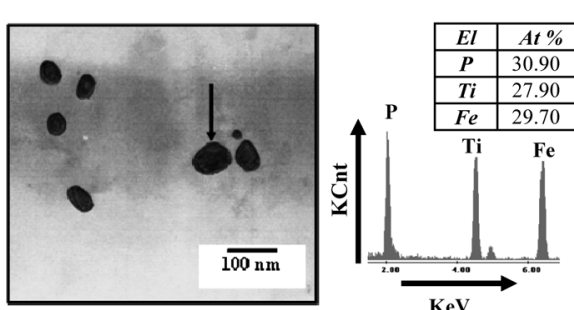

(c)

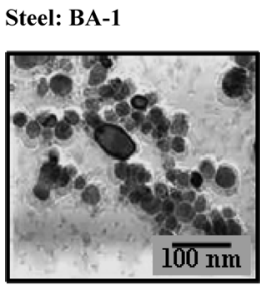

(e)

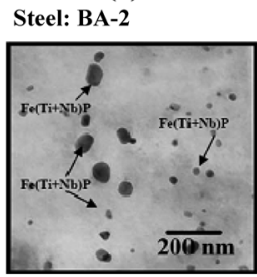

(j)

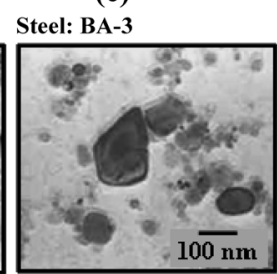

(f)

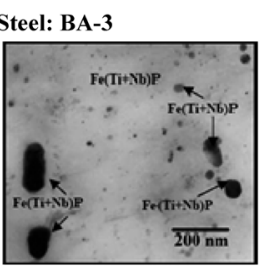

(k)

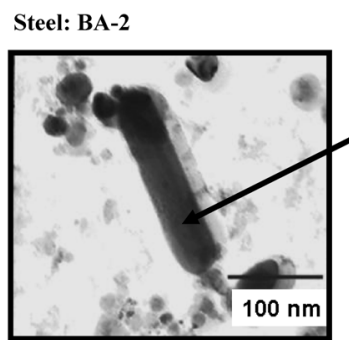

(b)

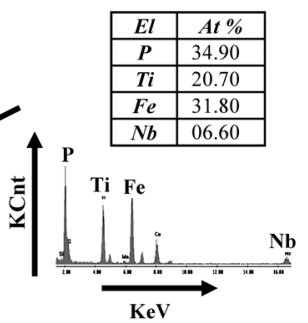

Steel: CA-1
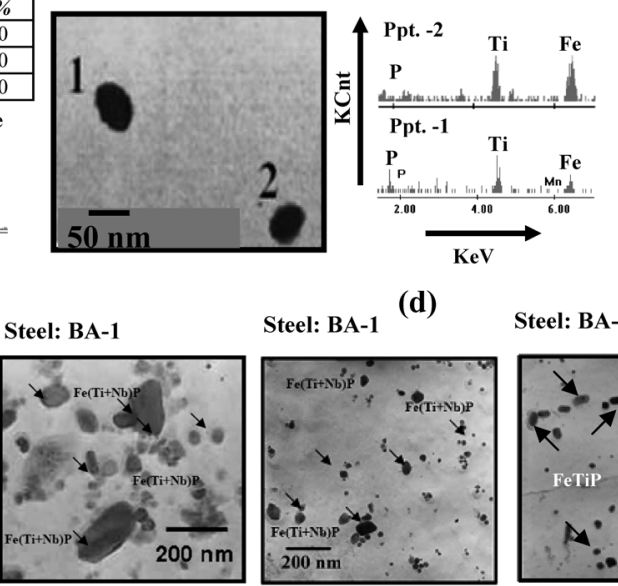

(g)

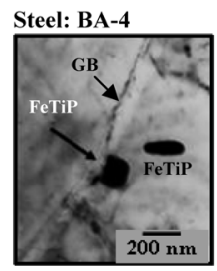

(I) (d)

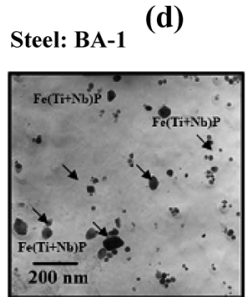

(h)

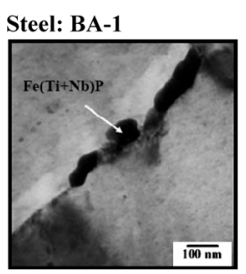

(m)

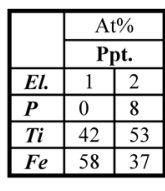

Steel: BA-4

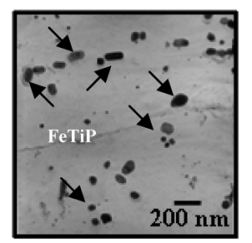

(i)

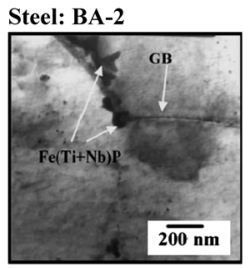

(n)

Fig. 5. TEM micrographs showing presence of FeTiP type of precipitates in the experimental steels. (a-g) Carbon extraction replica and $(\mathrm{h}-\mathrm{n})$ thin foil micrographs.

\section{High P, high Ti}

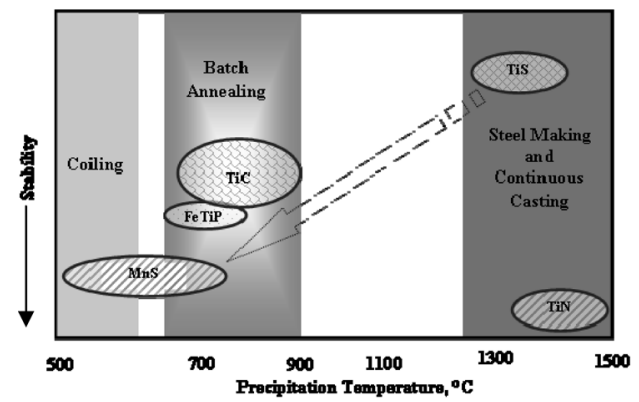

(a)

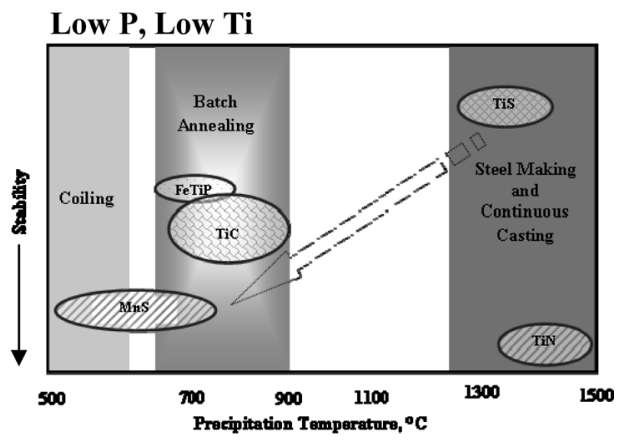

(b)

Fig. 6. Schematic illustrations of precipitation-composition-stability maps of the experimental batch annealed steels

that there is a possibility of competition for the formation of TiC and FeTiP. A higher P content is expected to promote the formation of FeTiP type precipitates. Formation of FeTiP type precipitates are more likely in BA-1 and this should be less probable in BA-2, BA-3 and BA-4, in that order. Therefore FeTiP type precipitates are expected to be more stable in the high P, high Ti steels. Figure 6 also gives an idea about the precipitation sequence at different stages of processing. During steel solidification and continuous casting, TiN and TiS will form. However, TiS is not stable at lower temperature. Thus it transforms into $\mathrm{MnS}$ during coiling and subsequent annealing treatment. This results in several $(\mathrm{Ti}+\mathrm{Mn}) \mathrm{S}$ precipitates in the steels. Free standing $\mathrm{MnS}$ also forms during coiling and annealing treatment.

\subsection{Effect of Precipitation on the Properties of IFHS Steels}

Although IF steels, being rather clean, normally show 


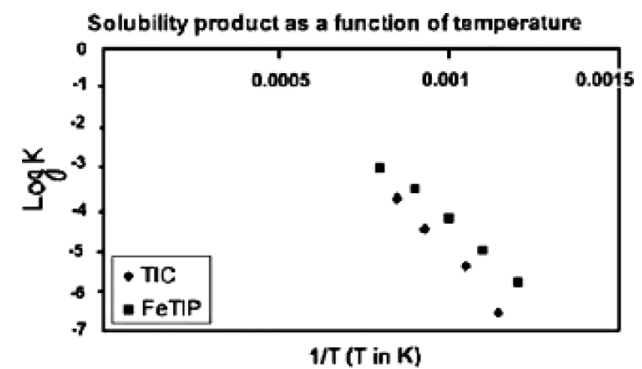

Fig. 7. Solubility product of $\mathrm{TiC}$ and FeTiP as a function of temperature in IF steels. ${ }^{27,28)}$

very little amount of precipitation, these precipitates may have a great impact on the properties, especially the formability. It has been reported by several researchers ${ }^{29,30)}$ that in IF steels, the removal of $\mathrm{C}$ from solid solution by the formation of precipitates will determine the development of the beneficial $\{111\}$ texture. Because of the much higher alloying element content of IFHS steels, the amount of precipitation may be higher than in case of the normal IF steels. In that case the effect of these precipitates on properties could be more pronounced also.

It has been observed that in IFHS steels there is a direct relationship of FeTiP precipitation with $\{111\}$ texture formation and thus formability. ${ }^{9,10)}$ In fact, higher the volume fraction of FeTiP precipitation, poorer is the texture and formability. FeTiP takes out Ti from the solid solution and the presence of small FeTiP particles on the grain boundaries may restrict the grain boundary migration. These will result in the non-availability of sufficient amount of Ti to tie up with carbon remaining in solid solution as well as restriction in the growth of the beneficial $\{111\}$ grains. Both will affect formability adversely. Simultaneously, the removal of $\mathrm{P}$ from the matrix as $\mathrm{FeTiP} / \mathrm{Fe}(\mathrm{Ti}+\mathrm{Nb}) \mathrm{P}$ will also lead to poorer strength of the IFHS steels. All these effects will be quite prominent in the BA-IFHS steels. However, in case of CA-IFHS steels, since FeTiP formation is rather restricted due to the very short annealing time available, this problem will be avoided to a large extent.

\section{Conclusions}

The following conclusions can be drawn from this study: In IFHS steels:

(1) TiN - forms during steel solidification and continuous casting and is very stable.

(2) TiS - forms during later stage of steel making and continuous casting. However stability is low at lower temperature and it may transform into $\mathrm{MnS}$ and very often results in the formation of $(\mathrm{Ti}+\mathrm{Mn}) \mathrm{S}$. Other than $\mathrm{MnS}$ and $\mathrm{TiS}, \mathrm{CuS}$ is also present.

(3) MnS forms, but $\mathrm{Ti}_{4} \mathrm{C}_{2} \mathrm{~S}_{2}$ does not form during annealing and coiling.

(4) There is a competition between $\mathrm{TiC}$ and FeTiP formation during batch annealing. Depending upon the $\mathrm{P}$ and Ti content of the steels, FeTiP may become more stable than TiC and thus may degrade the deep drawability. FeTiP hardly forms in continuously annealed steels.

(5) Presence of $\mathrm{Nb}$ improves the stability of TiS and may result in the absence of $\mathrm{MnS}$ in continuous annealed steels.

\section{REFERENCES}

1) B. C. De Cooman and A. De Vyt: Int. Forum for the Properties and Application of IF Steels, IF STEELS 2003, ISIJ, Tokyo, (2003), 249.

2) H. Takechi: ISIJ Int., 34 (1994), 1.

3) H. Takechi: IF STEELS 2000 PROCEEDINGS, Pittsburgh, (2000), 1.

4) M Hua, C. I. Garcia, K. Eloot and A. J. DeArdo: ISIJ Int., 37 (1997), 1129.

5) A. J. DeArdo: IF STEELS 2000 PROCEEDINGS, Pittsburgh, (2000), 125.

6) M Hua, C. I. Garcia and A. J. DeArdo: Scr. Mater, 28 (1993), 973.

7) M Hua, C. I. Garcia and A. J. DeArdo: Metall. Mater. Trans, 28A (1997), 1769.

8) G. Tither, C. I. Garcia, M. Hua and A. J. DeArdo: Int. Forum for Physical Metallurgy in IF Steels, The Iron and Steel Institute of Japan, Tokyo, (1994), 293.

9) P. Ghosh, R. K. Ray, B. Bhattacharya and S. Bhargava: Scr. Mater., 55 (2006), 271.

10) P. Ghosh, B. Bhattacharya and R. K. Ray: Scr. Mater, 56 (2007), 657.

11) P. Ghosh, R. K. Ray, C. Ghosh and D. Bhattacharjee: Scr. Mater, 58 (2008), 939.

12) P. Ghosh, C. Ghosh, R. K. Ray and D. Bhattacharjee: Scr. Mater., 59 (2008), 276.

13) R. Mendoza, J. Camacho, G. Lugo, C. Lopez, L. Herrera, J. Reyes, C. Gonalez and J. A. Juarez-Islas: ISIJ Int., 37 (1997), 176.

14) J. Kunze: Steel Res., 62 (1991), 430.

15) J. Kunze, B. Beyer, S. Oswalt and W. Gruner: Steel Res., 66 (1995), 161.

16) J. Kunze, C. Mickel, G. Bachman, B. Beyer, R. Reibold and C. Kleichenberg: Steel Res., 68 (1997), 441.

17) Y. Tokunaga and M. Tamada: US patent 4,504,326, (1985).

18) A. I. Fernandez, P. Uranga, B. Lopez and J. M. Rodriguez-Ibabe: Mater. Sci. Eng., A361 (2003), 367.

19) A. Okamoto and N. Mizui: Metallurgy of Vacuum Degassed Steel Products, ed. by R. Pradhan, TMS, The Minerals, Metals and Materials Society, Warrendale, PA, (1990), 161.

20) K. Tsunoyama, K. Sakata, T. Obara, S. Satoh, K. Hashiguchi and T. Irie: Hot and Cold Rolled Sheet Steels, ed. by R. Pradhan and G. Ludkovsky, TMS-AIME, Warraendale, PA, (1988), 155.

21) Pearson's Handbook of Crystallographic Data for Intermetallic Phases, ed. by P. Villars and L. D. Calvert, ASM, Metals Park, OH, (1985), 5154.

22) W. J. Liu, S. Yue and J. J. Jonas: Mater. Trans., 20A (1989), 1907.

23) G. Dupuis: Ph.D Thesis, USTL, Lille, (2001).

24) Y. Ishiguro, T. Murayama, K. Sato and K. Araki: CAMP-ISIJ, 10 (1997), 703.

25) P. Ghosh, R. K. Ray and D. Bhattacharjee: Scr. Mater, 57 (2007), 241.

26) D. Alaoua, S. Lartigue, A. Larere and L. Priester: Mater. Sci. Eng., A189 (1994), 155.

27) O. Hamart, T. Lung and S. Lanteri: 40th MWSP Conf. Proc., ISS, Warrendale, PA, (1998), 189.

28) T. Gladman: Physical Metallurgy of Microalloyed Steels, The Institute of Materials, (1977), 99.

29) W. B. Huchinson, K.-I. Nilson and J. Hirsch: Metallurgy of Vacuum Degassed Steel Products, TMS, Warrendale, PA, (1990), 109.

30) F. J. Held: Mechanical Working and Steel Processing Conference, ISS, Warrendale, PA, (1965), 3. 